\title{
Where Schumpeter was nearly Right - the Swedish Model and Capitalism, Socialism and Democracy*
}

\author{
By \\ Magnus Henrekson $\$ 1$ and Ulf Jakobsson ${ }^{2}$ \\ SSE/EFI Working Paper in Economics and Finance No 370
}

April 3, 2000

\begin{abstract}
In Capitalism, Socialism and Democracy Joseph A. Schumpeter concluded that socialism would eventually displace capitalism in Western democracies. This would come about as a result of the superior performance of capitalism. We extract six "stylized" propositions that are essential elements of Schumpeter's prediction about the fate of capitalism. These propositions are confronted with the development of the Swedish economy. The three main results of the analysis are:
\end{abstract}

(1) The evolution of the Swedish economy closely followed Shumpeter's predictions until about 1980: Large firms became increasingly predominant in production and innovative activity, ownership of firms became more and more concentrated, individual entrepreneurship waned in importance, the general public grew increasingly hostile towards capitalism, and by the late 1970s explicit proposals for a gradual transfer of ownership of firms from private hands were launched.

(2) Design of tax and industrial policies fueled a development of the economy along the lines predicted by Schumpeter. In general, the policies discouraged private wealth accumulation. In particular, the policies favored concentration of firms and concentration of private ownership.

(3) The turning point away from the path to socialism coincides with real world developments that disclosed two major flaws in Schumpeter's analysis. First, the ever more obvious failure of socialism in Eastern Europe went against Schumpeter's assertion that socialism can work. Second, Schumpeter, who thought that modern technology would make the giant corporation increasingly predominant, did not foresee the revival of entrepreneurship that took place in the Western countries around 1980.

JEL Classification: M13, O38, P16.

Keywords: Corporatism, Entrepreneurship, Industrial policy, Schumpeter, Swedish Model.

$\begin{array}{ll}\begin{array}{l}\text { †Corresponding author } \\ \text { 1Department of Economics }\end{array} & \text { 2IUI, the Research Institute of Industrial } \\ \text { Stockholm School of Economics } & \text { Economics } \\ \text { P. O. Box 6501 } & \text { P. O. Box 5501 } \\ \text { S-113 83 Stockholm } & \text { S-114 85 Stockholm } \\ \text { SWEDEN } & \text { SWEDEN } \\ \text { Phone: +46-8-7369202 } & \text { Phone: +46-8-665 45 02 } \\ \text { Fax: +46-8-313207 } & \text { Fax: +46-8-665 45 99 } \\ \text { e-mail: Magnus.Henrekson@hhs.se } & \text { e-mail: UlfJ@iui.se }\end{array}$

\footnotetext{
* We are grateful for excellent research assistance from Per Thulin and for useful comments and suggestions from Erik Dahmén, Mattias Ganslandt, Lars Jonung, Håkan Lindgren, Assar Lindbeck, Per-Martin Meyerson, Erik Norrman, Nathan Rosenberg, Richard Swedberg, Daniel Waldenström and the participants at a seminar at the Institute for Research in Economic History at the Stockholm School of Economics.
} 


\section{Introduction}

In Capitalism, Socialism and Democracy (CSD) Joseph Schumpeter raised the question whether capitalism as an economic system would be able to survive. He concluded that socialism would eventually displace capitalism also in Western democracies. Even if he thereby reached the same conclusion as Marx, his arguments were quite different. It was not the shortcomings or the instability of capitalism that produced the victory of socialism. Instead it was the superior performance of capitalism that paved the way for socialism.

Today we live in an era where the achievements of capitalism are far more obvious than when Schumpeter published his book in 1942. Yet, the introduction of socialism in the classical sense has disappeared from the political agenda in democratic countries. This does not necessarily mean that Schumpeter would have admitted that he was wrong in his prophecy. In his discussion of the time perspective he emphasizes the secular perspective: "...in these things a century is a short time." He also makes clear that there is no pure economic reason why capitalism should not have another successful round.

A further dimension is national diversity. Schumpeter underlined that different countries are unlikely to follow the same route to socialism. Looking at today's situation this observation does little to save Schumpeter's prophecy. For a long time, however, the development in the Swedish economy followed a path similar to the one laid out in CSD. As we will show this could to some extent be explained by economic policies that aimed at reinforcing the tendencies to follow the path that Schumpeter had predicted for capitalist economies. A concrete plan (wage-earner funds), that had the potential of transferring the ownership of the Swedish business sector to the labor unions, was introduced. If the original plan had been implemented, Sweden would have been very close to fulfilling all the parts in Schumpeter's prophecy. However, in hindsight it is clear that this plan marked a turning point in Swedish economic development. The plan was abandoned in the 1980s and Sweden has since then, as most other Western countries, developed in a way that has been contradictory to what Schumpeter predicted.

There is, however, a legacy from the old policies. The efforts to put the Swedish economy on a Schumpeterian path has contributed some idiosyncratic structural features to the Swedish economy, notably that Sweden ended up being dominated by large corporations to a larger extent than perhaps any other OECD country and that private ownership became very concentrated. In addition, private financial wealth became lower than in most industrialized countries. The combined effect of these features has, as we shall see below, contributed to a rapid increase in foreign ownership of the Swedish private sector, particularly following the internationalization of firms and financial markets. 
The aim of this article is to investigate to what extent the Swedish economy followed the Schumpeterian path and also to try to identify the factors that eventually set the Swedish economy on another course. A conclusion of our analysis is that Schumpeter's theory increases our understanding of Swedish economic history after World War II. But the analysis is also of a more general interest. Many of the Schumpeterian forces that were present in the Swedish economy were present in most Western democracies up until the mid to late 1970s, even if the tendencies were more pronounced in Sweden.

The paper is organized as follows. In the next section we briefly discuss the theory of evolution of the capitalist economy that was presented in CSD. The analysis of Schumpeter does not lend itself easily to simplifications. Still, we have extracted six stylized propositions that are essential elements of his prediction about the fate of capitalism. These propositions will in subsequent sections be confronted with data for the Swedish economy. The third section analyses the main ideas that were shaping economic policy during the first decades after World War II in Sweden. In many respects, the policies served to strengthen the tendencies in capitalist development that Schumpeter predicted would eventually lead to the victory of socialism. In particular, the policies contributed to a greater role for large corporations and to an increased concentration of firms and private ownership.

In the fourth section we examine the actual implementation of policies and discuss their relation to the general ideas that were analyzed in section 3 . In section 5 we confront the development in the Swedish economy up until the beginning of the 1980s with the stylized propositions derived in section 2. Section 6 contains an examination of the effort to replace private ownership by wage-earner funds, and we try to identify the factors that eventually led to a reversal of policies. In section 7 we discuss the development of the Swedish economy after the abolition of wage-earner funds and the subsequent reversal of policies. Section 8 concludes.

\section{The Propositions in Capitalism, Socialism and Democracy}

Few economists have done more than Joseph Schumpeter did in The Theory of Economic Development $(1911,1934)$ to increase our understanding of the role of the entrepreneur in the capitalist economy. In particular, he asserted the crucial role of the entrepreneur in the process of innovation and creative destruction - today it is virtually impossible to conceive of a dynamic capitalist economy in the absence of the Schumpeterian entrepreneur. 
However, in his late work Schumpeter (1942) saw the declining economic importance of the entrepreneur as one of the major forces in the transformation from capitalism to socialism. Schumpeter claimed that by means of modern techniques and modern modes of organization the innovation process would become more and more automated. Innovations would no longer be connected with the efforts and the brilliance of a single person. They were increasingly to become the fruits of the organized effort of large teams. This would be done most effectively within the framework of large corporations. ${ }^{1}$

By using the proceeds from its monopoly power to finance new innovations, the large corporation could improve its monopoly position and in practice crowd out entrepreneurs and smaller firms. Schumpeter went as far as saying that the entrepreneurial function would become obsolete. Like Marx, he therefore predicted that the economy to an increasing extent was going to be dominated by large corporations. Unlike Marx, and for that matter Veblen (1923), Schumpeter did not foresee any problems of economic stability or economic efficiency for the capitalist system. Instead, capitalism would kill itself by undermining its political base by its own efficiency; the forces of creative destruction would eventually kill capitalism itself.

The entrepreneurs were, according to Schumpeter, the backbone of the bourgeoisie, thus providing capitalism with its institutional and political basis. By destroying the entrepreneurs through its effectiveness, capitalism would also destroy its own political foundation. In an economy that is increasingly dominated by giant corporations and devoid of entrepreneurs, the defense of capitalism has no constituency. Instead, capitalism will have to confront increasing hostility. Here the intellectuals were, according to Schumpeter, going to play an important role in formulating a criticism against the capitalist system and its institutions. Eventually, a democratic and peaceful transformation of the economy to socialism would take place.

While Schumpeter discussed the role of the intellectuals in the downfall of capitalism at great length, he was very brief on the role of the labor movement in this phase. He refers to the labor movement in connection with the discussion of the intellectuals, where he maintains that the intellectuals will invade labor politics and contribute to a radicalization of the labor movement. He did, however, come back to the labor movement more directly in later writings. There he wrote that labor would dominate the political scene in the last stage of capitalism. For instance, he criticized Lenin for saying that imperialism would be the last stage of capitalism. According to Schumpeter this was all wrong. Instead he maintained that

\footnotetext{
${ }^{1}$ See Rosenberg (2000) for a thorough elaboration of this issue from today's vantage point.
} 
laborism is the last stage of capitalism. Laborism is characterized by Schumpeter as that stage in capitalist society in which the labor interest is predominant (Swedberg, 1997, p. 119).

We have presented a very brief account of the scenario that Schumpeter (1942) envisaged for capitalism in the chapter named "Crumbling Walls". From Schumpeter's scenario we extract the following stylized propositions:

1. The bulk of innovations will be made in large corporations.

2. Large corporations will be increasingly predominant in the economy.

3. New and smaller firms will play a declining role in the economy.

4. The concentration of ownership will grow over time.

5. The general public, not least the intellectuals, will grow increasingly hostile towards capitalism

6. Socialism will eventually replace capitalism.

The eventual defeat of capitalism was an unconditional forecast by Schumpeter.

Technological change, political development and even the intellectual debate were all endogenous parts of Schumpeter's scenario. There was therefore no room for a political effort to save capitalism. On the other hand it was from the point of view of the socialist parties important to let events run their course. Attempts to introduce socialism before the time was ripe could result in failure. (See Schumpeter's discussion on "transition" in CSD, pp. 227-229.)

In the rest of our article we will show that propositions 1-5 stand up well against the actual development of the Swedish economy during the first four decades after WW II. As we will see, Sweden also came close to fulfilling prediction 6 .

It goes without saying that the process of private wealth creation plays a crucial role in the capitalist system. This process was also at the center of Marx's analysis of the rise and fall of capitalism. In fact, Schumpeter is unclear on this point. Therefore it is not possible to extract a simple and clear-cut proposition from $C S D$ on this matter. When Schumpeter discussed the increasing concentration of ownership he was referring to direct ownership. In his scenario households would own shares in the big companies. This would not, however, in his view make people attached to the companies or to the capitalist system. Even if Schumpeter did not express a clear and comprehensive view on the role of private wealth formation, we will analyze the role of this factor in the development of the Swedish economy. We will do so firstly because private wealth formation is an integral part of an entrepreneurial society. Even in Schumpeter's giant corporation scenario a high savings rate is necessary. These savings have to be generated somewhere. In the Swedish case, government policies towards savings 
played an important role in moving the Swedish economy along on the Schumpeterian road towards socialism. This constitutes our second reason for analyzing the development of savings and savings policies in this article.

\section{The Ideas behind Economic Policy in Sweden after World War II²}

For 44 years, from 1932 to 1976, the Social Democrats held the political power in Sweden. Despite nine years of nonsocialist governments (1976-82 and 1991-94) it is fair to say that the Social Democrats have dominated the political scene and the policy discussion since the early 1930s until the present day. As a result, there is little doubt that its philosophy had a tremendous influence on political decisions impinging on entrepreneurs, firms, private versus collective ownership and the overall business climate. In view of this circumstance, we will focus on relaying the ideas advanced by Social Democratic thinkers on the issues of interest here. It is apparent that the most important Social Democratic thinkers have seen the large industrial corporation as the major unit of production. Ernst Wigforss, Minister of Finance in 1925-26 and 1932-49 and probably the most influential of all Social Democratic ideologues, is quite clear on this point. For instance, in his essay on CSD (Wigforss, 1956) he seems to agree with Schumpeter on the inevitability of the movement in capitalist societies towards progressively larger companies.

Among leading Social Democrats at the time, the well-read Wigforss was probably alone in his good knowledge of Schumpeter's work. A more influential theorist in the Social Democratic movement was of course Karl Marx, whose wievs on the development of the capitalist society had clear connections with Schumpeter's. The Norwegian sociologist Gudmund Hernes (1991) has emphasized the connection between Karl Marx's theory of the development of industrial societies and the Nordic Social Democratic Model. A key factor in Marx's theory was the importance of economies of scale, which would gradually lead to the phasing out of small firms as well as several of the less competitive large firms.

Wigforss does not find Schumpeter's and Marx's prediction, that small and new firms are dwindling in importance, disquieting. Instead he seems to argue that this trait of capitalist societies will facilitate the collectivization or socialization of the productive capital stock, which is the ultimate goal of the labor movement. Furthermore, Wigforss (1952, pp. 125126) finds it essential to focus on the large industrial corporation for non-economic reasons:

\footnotetext{
2 Johansson and Magnusson (1998) provide a comprehensive account of the issues dealt with in this section. See also Lindbeck (1997).
} 
That is where the adversarial relationship between owners and employees is most fundamental, and where the collective form of ownership and management can be most easily used as a means to achieve more equality, freedom and solidarity (authors' translation).

In the tradition of Wigforss, the Social Democratic economist Villy Bergström (1973) sketches a strategy for a step-by-step transition from private to collective ownership of the means of production. Bergström was also convinced that the pertinent unit to focus on is the large industrial corporation: "Throughout I consider the large industrial corporation as the incarnation of 'the firm'" (p. 8). ${ }^{3}$

Thus, the notion that large-scale production and a social order with strong collectivist elements were conducive to economic development had considerable appeal at the time, and it was easy to find inspiration from contemporaneous social scientists. In particular, John Kenneth Galbraith, who was undoubtedly greatly inspired by Schumpeter (1942), was instrumental. Especially his book The New Industrial State (1967) provided an important rationale for an economic policy oriented towards the large corporation. 4

Thus, by the late 1960s it was quite clear that the Social Democrats considered small firms and individual entrepreneurs as marginal elements in the process of economic development, and in due course such phenomena would be totally anachronistic. But what about the ownership and control of these large production units?

Somewhat surprisingly, in Fackföreningsrörelsen och den fulla sysselsättningen (Trade Unions and Full Employment), a major policy document from the Confederation of bluecollar workers (LO) published in 1951 (in English as LO, 1953), it is difficult to find any bias favoring large companies or institutionalized private ownership, although there is a clear inclination towards the view that collective ownership and state ownership should gain in importance.

This inclination is in line with Wigforss' stance on the ownership issue. He maintained that in the long run the large industrial corporations had to be converted into "social enterprises without owners" (samhällsföretag utan ägare). In these enterprises individuals could still be shareholders, but the shareholders were no longer residual claimants; wages should be set in wage negotiations, dividends should be related to the level of interest rates in capital markets, and all excess profits should remain within the companies.

\footnotetext{
3 In Swedish: "Jag har hela tiden de stora industriföretagen framför mig som sinnebilden av 'företaget'”. 4 One indication of Galbraith's great impact on Swedish policy makers is that shortly after the publication of The New Industrial State he was invited by the then Prime Minister Tage Erlander to his official summer residence Harpsund to give a two-day seminar on his book to the members of the government.
} 
For the trade unions and for Wigforss collective ownership of the means of production was the ultimate political goal. In this perspective a strong concentration of ownership could be seen as a natural and even desirable intermediate station on the road towards the ultimate goal. The strong concentration of ownership alienated the Swedish constituency from capitalist values and could be expected to contribute to a broad-based support for the industrial policies of the Social Democratic party.

If a strong concentration of ownership is seen as undesirable from a political point of view, an alternative to the policies actually pursued would have been a policy supporting a less concentrated and more broad-based individual ownership of the corporate sector. But such a policy would have run counter to the long-term goals of the Social Democratic party. However it should have been a very natural political course for the nonsocialist parties. Since they did not get into government until 1976 they never had the opportunity to pursue such a policy. Neither did they, during the 50s and the 60s, manage to create a broad-based support among Swedish voters for such a policy.

As we shall see, the industrial policies actually pursued promoted a development of the economy towards the visions of LO and Wigforss. In contrast, there were up until the middle of the 70s very few attempts, by direct measures, to transfer ownership of corporations from private hands to the government. However some steps were taken - especially in mining, steel and forestry - to increase direct state ownership of the corporate sector. In 1970 the central government founded Statsföretag $A B$, a large conglomerate to which most of the state-owned enterprises were transferred. No doubt, many politicians saw this as an offsetting force to private owners. Still, state ownership of the industrial sector was among the lowest in the OECD countries in the 1970s (Lybeck, 1984).

This policy has been named "the historical compromise" (Korpi, 1982). The industrial elite acknowledged and accepted that the Social Democrats by virtue of their political strength would use the political power to implement far-reaching welfare reforms, while the labor movement, on their part, abstained from socializing the industrial sector. Among the ideologues in the social democratic party this historical compromise was certainly seen as a temporary arrangement. The industrial policy was working towards the goals set out by Wigforss and LO and within the labor movement the debate on "the third step of socialism", i.e., the abolition of private ownership to the means of production, was alive. 


\section{Reinforcing Economic Policies}

Schumpeter's conclusions in $C S D$, summarized in our six propositions, primarily follow from his analysis of the nature and functioning of capitalism, where inexorable internal forces are said to result in the eventual demise of capitalism. A natural extension of Schumpeter's analysis would be to examine whether different economic policies would precipitate or decelerate this allegedly inevitable development. In this section we will show how Swedish economic policies from the 1950s through the 1970s were designed so that they directly encouraged the fulfillment of propositions 2-4. These policies therefore paved the way for the realization of propositions 5 and 6, i.e., an increasing hostility towards capitalism in the population and the eventual transition to socialism.

\subsection{Tax Policies}

Several features of the pre-1990 Swedish tax system disfavored younger, smaller and less capital-intensive firms, and discouraged entrepreneurship and family ownership in favor of institutional forms of ownership. Several important distortions stemmed from high statutory rates of corporate income taxation coupled with other policies that resulted in much lower effective tax rates. The statutory corporate income tax rate remained in the very high range of 50-62 percent from the early 1950s until 1990. Beginning in 1958, a large gap emerged between statutory and effective (average) tax rates as a result of accelerated depreciation rules, the so-called investment fund system, inventory valuation rules, and other ad hoc tax reductions. However, their usefulness as tax avoidance mechanisms differed greatly across industries and types of firms. A clear and important example was the liberal provisions for accelerated depreciation of machinery and equipment. These provisions favored machineintensive manufacturing industries over service-producing industries. More generally, the depreciation rules disfavored firms and sectors that were intensive in human capital, financial capital and intangible forms of capital. See Södersten $(1984,1993)$ and Davis and Henrekson (1997) for further details.

High statutory tax rates favor a reliance on debt rather than internally generated funds or new share issues to finance investments. However, the ability to exploit the tax advantages of debt financing differed among industries and firms. In particular, to the extent that debt financing is less costly and more readily available for larger, more established firms, high statutory tax rates coupled with tax-deductible interest payments work to the disadvantage of smaller firms and potential entrants. Debt financing is also more easily available to firms with ready forms of collateral. Hence, firms and sectors that more intensively use physical capital reap greater 
benefits from tax code provisions that favor debt financing. In practice, this aspect of the tax system favored the capital-intensive manufacturing industries relative to other industries. ${ }^{5}$

Table 1 Effective Marginal Tax Rates for Different Combinations of Owners and Sources of Finance, 1960, 1970, 1980, 1985 and 1991 (real pre-tax rate of return $10 \%$ at actual inflation rates).

\begin{tabular}{lrrr}
\hline & Debt & $\begin{array}{r}\text { New share } \\
\text { issues }\end{array}$ & $\begin{array}{r}\text { Retained } \\
\text { earnings }\end{array}$ \\
\hline $\mathbf{1 9 6 0}$ & & & \\
Households & 27.2 & 92.7 & 48.2 \\
Tax exempt institutions & -32.2 & 31.4 & 31.2 \\
Insurance companies & -21.7 & 41.6 & 34.0 \\
$\mathbf{1 9 7 0}$ & & & \\
Households & 51.3 & 122.1 & 57.1 \\
Tax exempt institutions & -64.8 & 15.9 & 32.7 \\
Insurance companies & -45.1 & 42.4 & 41.2 \\
1980 & & & \\
Households & 58.2 & 136.6 & 51.9 \\
Tax exempt institutions & -83.4 & -11.6 & 11.2 \\
Insurance companies & -54.9 & 38.4 & 28.7 \\
1985 & & & \\
Households & 46.6 & 112.1 & 64.0 \\
Tax exempt institutions & -46.8 & 6.8 & 28.7 \\
Insurance companies & -26.5 & 32.2 & 36.3 \\
1991 & & & \\
Households & 31.7 & 61.8 & 54.2 \\
Tax exempt institutions & -9.4 & 4.0 & 18.7 \\
Insurance companies & 14.4 & 33.3 & 31.6 \\
\hline
\end{tabular}

Note: All calculations are based on the actual asset composition in manufacturing. The following inflation rates were used: 1960: 3\%, 1970: 7\%, 1980: 9.4\%, 1985: 5\%, 1991: 5\%. The calculations conform to the general framework developed by King and Fullerton (1984). The average holding period is assumed to be 10 years. A negative tax rate implies that the rate of return after tax is greater than before tax. For instance, a tax rate of -83 percent for a debt-financed investment owned by a tax-exempt institution in 1980 tells us that a real rate of return of 10 percent before tax becomes 18.3 percent after tax.

Source: Calculations provided by Jan Södersten, see Södersten $(1984,1993)$.

To provide a sense of the magnitude of the distortions introduced by the Swedish tax system, Table 1 presents effective marginal tax rates for different combinations of owners and sources of finance for selected years between 1960 and 1991. Three categories of owners and sources of finance are identified, and the effective marginal tax rate is calculated assuming a

\footnotetext{
5 Södersten (1984) shows that during the 1960s the effective marginal tax rate on manufacturing was considerably lowered relative to that of other industry and commerce.
} 
pre-tax real rate of return of 10 percent. A negative number means that the real rate of return is greater after tax than before tax.

The table highlights four important aspects of the Swedish tax system during the postwar period through the 1980s. First, debt financing consistently received the most favorable treatment and new share issues the least. Second, retained earnings were consistently taxed at lower rates than newly issued equity, which favored incumbent firms relative to entrants. Third, the taxation of households as owners was much higher than for other categories, and their rate of taxation increased during the 1960s and 1970s, whereas the reverse occurred for insurance companies and tax-exempt institutions. ${ }^{6}$ From some point in the 1960s until the 1991 tax reform, more than 100 percent of the real rate of return was taxed away for a household buying a newly issued share. Fourth, tax-exempt institutions benefit from a large tax advantage relative to the other two categories of owners, and this advantage increased strongly during the 1960s and 1970s. ${ }^{7}$

How do these distortions in the Swedish tax system compare to other countries? To partially address this question, Table 2 reports corporate tax wedges for investments in machinery, buildings and total business capital (an aggregate of machinery and buildings) in several OECD countries as of 1985 . According to the table, the marginal tax wedges were invariably negative, which means that after-tax rates of return exceed pre-tax rates of return. Among all listed countries, Sweden exhibited the largest negative wedges and hence the largest corporate-tax bias towards capital-intensive firms and industries.

\footnotetext{
6 Tax-exempt institutions by definition pay no tax on interest receipts, dividends or capital gains. This category includes charities, scientific and cultural foundations, foundations for employee recreation set up by companies, pension funds for supplementary occupational pension schemes, and the National Pension Fund (the AP Fund). In terms of industry ownership and control, tax-exempt institutions have a dominant position in Sweden.

7 The calculations for households are based on an average household, but households owning a successful business typically faced an even higher tax rate because of the combined effect of wealth and income taxation. Until 1992, wealth tax was levied on 30 percent of the net worth of a family-owned company, incorporated or not. As of the mid-1980s, the maximum wealth tax rate was 3 percent. Since the wealth tax was not deductible at the company level, funds required to pay the wealth tax were first subject to the personal income tax and the mandatory payroll tax.
} 
Table 2 The Estimated Marginal Tax Wedge for Business Capital at a 5 Percent Real Interest Rate and the 1985 Inflation Rate (percentage points).

\begin{tabular}{lrrr}
\hline & Machinery & Buildings & $\begin{array}{r}\text { Total business } \\
\text { capital }\end{array}$ \\
\hline U.S. Old $\quad$ New & -5.26 & -2.41 & -3.25 \\
Japan & -2.32 & -0.68 & -1.16 \\
Germany & $-1,67$ & -0.81 & -1.08 \\
France & -2.37 & -2.40 & -2.38 \\
U.K. Old & -3.45 & -3.29 & -3.35 \\
$\quad$ New & -5.55 & -3.21 & -4.58 \\
Italy & -3.03 & -1.67 & -2.46 \\
Canada Old & -3.85 & -3.95 & -3.91 \\
& -3.61 & -2.22 & -2.77 \\
Australia New & -1.53 & -1.28 & -1.38 \\
Belgium & -7.98 & -2.31 & -4.78 \\
Netherlands & -6.95 & -4.39 & -5.51 \\
Spain & -4.52 & -2.17 & -3.20 \\
Sweden & -6.21 & -4.64 & -5.32 \\
\hline
\end{tabular}

Source: Fukao and Hanazaki (1987).

For a smaller set of countries, King and Fullerton (1984) report effective marginal tax rates by ownership category, accounting for both corporate and personal income taxes. In that study Sweden was the only country where more than 100 percent of the real return was taxed away in 1980 for households making corporate investments. ${ }^{8}$ Sweden also exhibited the most favorable treatment of tax-exempt institutions. While strongly discouraging direct household ownership of business, the Swedish tax system has generously subsidized investment in the housing stock. Fukao and Hanazaki (1987) show that housing investment received preferential tax treatment in all investigated countries, but more so in Sweden.

\subsection{Credit Market and Savings Policies}

As already mentioned briefly in section 2, an entrepreneurial economy is highly dependent on private savings to retain its dynamism. However, Schumpeter (1942) - and, for that matter, Karl Marx - foresaw a decline in the rate of return of savings as the most profitable investment opportunities were gradually depleted. At the same time, a high aggregate savings and investment rate was an essential part of Swedish economic policy during the first decades

\footnotetext{
8 This high figure comes about even though it may be presumed that, within each country, owners choose an asset distribution that is reasonably optimal relative to the tax system they face.
} 
of the postwar period (Bergström, 1982). But achieving a high rate of aggregate savings without allowing strong economic incentives to private individual wealth accumulation was not possible without a number of additional measures such as large surpluses in the public sector and a highly regulated credit market. As we will see, these policies can also be expected to reinforce the tendencies put forth by Schumpeter in $C S D$.

Throughout the postwar period until the late 1980s, the Swedish credit market was highly regulated. Inspired, among other things, by Gunnar Myrdal's 1944 paper on "high taxes and low interest rates", Swedish credit market policy was for a long time aimed at low interest rates for favored sectors of the economy. The credit volume to the industrial sector was generally subjected to quantitative restrictions and the rate of interest was also regulated, which resulted in a situation of virtually continuous credit rationing. These developments continued until the early 1980s, when a rapid process of deregulation began. The process was completed in 1989, when the remaining foreign exchange controls were lifted. This set of regulations clearly favored credit access by larger, older, firmly established firms and by real capital-intensive firms with ready sources of collateral. See Jonung (1994) and Henrekson (1992).

The mandatory national pension system (ATP) instituted in 1960 transformed the public sector into the most important supplier of credit. Large surpluses were accumulated in the national pension funds, the so-called AP funds. In the early 1970s, the AP funds accounted for 35 percent of total credit supply (Pontusson, 1992). The decision to accumulate savings to such a great extent in the AP funds led to a massive further institutionalization of savings, which can be expected to have benefited large, well-established firms with a good credit rating that could operate on a high debt-equity ratio. ${ }^{9}$

The structure of the Swedish tax and pension system reduced incentives for individual wealth accumulation in general and not only in the form of corporate equity. The availability of equity financing is a critical factor for both start-ups and the expansion of incumbent firms. In general, the riskier the business, the greater the reliance on equity relative to debt financing. The existence of collateral notwithstanding, a sizable infusion of equity is often a prerequisite to obtain credits. In addition, a large infusion of equity by the owners signals their belief that the project offers favorable risk and return characteristics, which increases the willingness of banks and other outsiders to grant credit.

\footnotetext{
${ }^{9}$ The gradual introduction of mandatory supplementary pension schemes can be expected to have the same effect.
} 
The smaller and newer the firm, the more difficult for outside financiers to assess the viability and profitability of the proposed investment project. Thus, ceteris paribus, small and newly established firms are more dependent on equity financing than large, wellestablished firms. Low private savings exacerbates the inherent problem caused by asymmetric information. Also, given the level of wealth or national savings, the composition of national savings is not neutral in its impact on entrepreneurship and small business development. The manner in which savings are channeled to various investment activities influences the type of business organization that can obtain credit. Pension funds, for example, are less likely to channel funds to entrepreneurs than business angels or venture capital firms. Hence, if the government forces individuals to carry out most of their savings through a national pension fund system, small business credit availability can be expected to suffer relative to an alternative policy that allow for greater choice by individuals regarding their savings and investments.

A distinct point is that there is substantial scientific evidence supporting the idea that the individual wealth position has important effects for the probability of becoming an entrepreneur and for the propensity to expand. This has been interpreted as showing that entrepreneurs face liquidity constraints (Evans and Leighton, 1989; Evans and Jovanovic, 1989). However, other interpretations of the positive correlation between family assets and the propensity to become an entrepreneur and/or expand an extant business are feasible. First, inherently acquisitive individuals may both start businesses and forgo leisure to accumulate assets. Second, the positive correlation may largely be due to the fact that the movement into self-employment arises because children tend to inherit family firms. Recently, studies have been made where these potential biases are avoided. Blanchflower and Oswald (1998) find that the likelihood of starting a business in Britain increases significantly among those who receive an inheritance or a gift. Lindh and Ohlsson (1996) arrive at the same conclusion for Sweden when studying people who receive a lottery gain. ${ }^{10}$ Holtz-Eakin, Joulfaian and Rosen (1994) find that within the group of self-employed in the U.S. at the beginning of the 1980s, the receipt of an inheritance had a statistically significant positive effect on both the likelihood of remaining in business and on the expansion of the firm. In summary, strong empirical evidence points to the importance of personal assets for the degree to which entrepreneurial talent is exploited.

The evidence that individual wealth matters for the deployment of entrepreneurial talent lends support to Knight's (1921) view that risk bearing and ownership are inextricable aspects of entrepreneurship. This is in contrast to Schumpeter $(1911,1934)$ who argued that

10 See also Van Praag and Van Ophem (1995). 
the functions of the entrepreneur and the risk-bearing capitalist could be separated. Our view, supported by the evidence reviewed here, is that entrepreneurship, ownership and riskbearing cannot be fully separated. Hence, policies and institutions that channel assets away from individual control will curtail the deployment of entrepreneurial talent and drive.

\subsection{Conclusions}

Thus, we may conclude from this section that from the 1950s until the 1980s a large number of policy measures were implemented that had the effect of directly reinforcing the first four Schumpeterian propositions. In particular, taxation of businesses became increasingly unfavorable for individual owners and favorable for debt-financed investments. In combination with a policy of highly regulated credit markets and low incentives for personal savings, one would expect these policies to reinforce the first four Schumpeterian propositions. As a corollary, propositions 5 and 6 could be expected to come true in due course.

\section{The Propositions and the Swedish Economy}

In this section we will explore to what extent the actual development in the Swedish economy after WW II fits the propositions put forward in section 2. Starting with proposition 1, the question where the innovations in Swedish industry were made, was studied in Granstrand and Alänge (1995). From a unique data set containing the 100 major innovations in Swedish industry during the postwar period, the authors conclude that more than 80 percent of those innovations took place in large Swedish firms. Thus, proposition 1 seems to square with Swedish data. Whether the reason for this is that the innovation process generally is routinized and automated is however not possible to say. The result could simply be a reflection of the large share of big firms in the Swedish economy, which in its turn could have other explanations than the routinization and automation of the innovation process. The result shows, however, that the individual entrepreneur has not been an essential ingredient in the Swedish innovation process. ${ }^{11}$ Lindholm Dahlstrand (1997) describes this as a particular Swedish large-firm model of high tech innovation.

\footnotetext{
11 Granstrand and Alänge (1995) also briefly discuss the general question whether Schumpeter's proposition that socialism will replace capitalism is right in the case of Sweden. By looking at the present situation they conclude that Schumpeter was wrong. Our conclusion is different, mainly because we are looking at the development of the Swedish economy during the whole period after WW II.
} 
Let us now turn to propositions 2 and 3 that obviously are closely interconnected. During the 1980s, the self-employment rate in Sweden stabilized at a low level relative to Sweden's historical experience and relative to the contemporaneous situation in other countries. Since the early 1970s until 1990, Sweden exhibited the lowest ratio of nonagricultural selfemployment to civilian employment among all OECD countries (OECD Employment Outlook, July, 1992). The European Observatory for SMEs (1995) reports that Sweden had a lower self-employment rate in 1992 than any of the then 12 member countries of the European Community (EC). The Swedish self-employment rate was found to be less than one-half the EC average.

The European Observatory for SMEs (1995) provides complementary evidence on the relatively small role of small firms in Sweden. Among 16 European countries, Sweden shows the largest value for mean enterprise size in 1990. Average enterprise size is 13 employees in Sweden, more than twice the corresponding average value for the 16 European countries.

A number of measures comparing the predominance of large firms across countries are available. In relation to the size of the economy, hardly any other country has as many large firms as Sweden. Jagrén (1993) calculated how many firms on the Fortune 500 list (covering the world's 500 largest businesses) that come from each country and compared this figure with the GDP. His calculations are reproduced in Table 3. Relative to GDP, Sweden proved to have twice as many Fortune-500 firms than Japan and the U.K., and four times as many as the U.S. and Germany. Even compared to other countries dominated by large firms, such as Finland and South Korea, the number of large firms relative to GDP was substantially greater. 
Table 3 The Number of Fortune 500 Firms in Various Countries, 1991.

\begin{tabular}{lrr}
\hline Country & No. of Fortune 500 firms & No. of firms per GDP unit \\
\hline United States & 157 & 0.028 \\
Japan & 119 & 0.050 \\
United Kingdom & 45 & 0.050 \\
Germany & 33 & 0.026 \\
France & 32 & 0.031 \\
Sweden & 15 & 0.104 \\
South Korea & 13 & 0.070 \\
Switzerland & 10 & 0.067 \\
Netherlands & 9 & 0.036 \\
Italy & 7 & 0.007 \\
Finland & 6 & 0.075 \\
Norway & 3 & 0.042 \\
Denmark & 0 & 0.000 \\
\hline
\end{tabular}

Note: One GDP unit is defined as one billion USD (PPP adjusted).

Source: Jagrén (1993).

In Table 4 the average number of enterprises in different size classes in European countries is calculated for the period 1988 to 1991 . The average number is then used to calculate the size distribution of firms. ${ }^{12}$ On average, Sweden has the greatest number of large industrial firms per capita among the countries compared. Here Sweden is followed closely by Germany, but then there is a leap to Finland. In terms of medium-sized industrial firms per capita Sweden is about average, while it ranks below average in the small size class. The impression that Sweden has many large but comparatively few small firms compared to other European countries is strengthened when we analyze the size distribution of firms. Sweden still ranks as number 1 in the large size class, and the distance to the 2nd ranking country is greater. Sweden also has a large share of medium-sized firms according to this definition. The share of small-sized industrial firms, however, is reported to be the second smallest among the countries included in the comparison.

The interpretation of these cross-country comparisons of average firm size and size distribution of firms is clouded by ambiguities in the economic concept of a firm, by differences among countries in the legal definition of a firm, and by differences in measurement procedures. Despite these interpretational difficulties, there seems little doubt that Sweden's reputation as a land of big business was well founded in the late 1980s and early 1990s. If anything, the raw figures fail to fully convey the extent of concentrated

12 The number of countries included is governed by data availability. See Henrekson and Johansson (1999). 
ownership and control in Sweden. In this regard, Fölster and Peltzman (1997) note that the five largest final owners ${ }^{13}$ in 1985 held roughly 44 percent of the total voting rights in companies with more than 500 employees, and the ten biggest had more than half. In addition, these final owners held shares through intermediaries, which in turn were linked through joint ownership. Fourteen such groups dominated the corporate sector, with three major ones alone controlling companies that accounted for some two-thirds of employment, sales and total assets of the 270 largest corporations in Sweden.

Table 4 The Average Number and the Size Distribution of Firms per Million Inhabitants in the Industrial Sector, 1988-91 (rank in parentheses).

\begin{tabular}{lrrrrrrr}
\hline & \multicolumn{3}{c}{ Firms per million inhabitants } & \multicolumn{3}{c}{ Size distribution } \\
& Small & \multicolumn{1}{c}{ Medium } & Large & Small & Medium & Large & Sum \\
\hline Germany & $1187(3)$ & $144(2)$ & $33(2)$ & $87.0(7)$ & $10.6(6)$ & $2.4(6)$ & 100 \\
France & $669(10)$ & $84(9)$ & $19(10)$ & $86.7(8)$ & $10.9(5)$ & $2.4(6)$ & 100 \\
U.K. & $650(12)$ & $75(11)$ & $22(5)$ & $87.1(6)$ & $10.0(7)$ & $2.9(4)$ & 100 \\
Sweden & $774(8)$ & $112(5)$ & $34(1)$ & $84.1(11)$ & $12.1(2)$ & $3.7(1)$ & 100 \\
Italy & $1365(2)$ & $77(10)$ & $11(11)$ & $93.9(1)$ & $5.3(12)$ & $0.8(12)$ & 100 \\
Spain & $1055(5)$ & $74(12)$ & $10(12)$ & $92.6(2)$ & $6.5(11)$ & $0.9(11)$ & 100 \\
Belgium & $678(9)$ & $91(7)$ & $21(6)$ & $85.8(10)$ & $11.6(3)$ & $2.6(5)$ & 100 \\
Portugal & $1504(1)$ & $161(1)$ & $21(6)$ & $89.2(4)$ & $9.5(9)$ & $1.3(10)$ & 100 \\
Denmark & $1131(4)$ & $124(4)$ & $21(6)$ & $88.7(5)$ & $9.7(8)$ & $1.6(9)$ & 100 \\
Luxembourg & $668(11)$ & $141(3)$ & $26(4)$ & $80.1(12)$ & $16.9(1)$ & $3.1(2)$ & 100 \\
Finland & $787(7)$ & $101(6)$ & $27(3)$ & $86.0(9)$ & $11.1(4)$ & $3.0(3)$ & 100 \\
Norway & $895(6)$ & $86(8)$ & $21(6)$ & $89.3(3)$ & $8.6(10)$ & $2.1(8)$ & 100 \\
Average & 947 & 106 & 22 & 87.5 & 10.2 & 2.2 & 100 \\
\hline
\end{tabular}

Note: Small, medium and large firms are defined as firms with 10-99, 100-499 and 500+ employees, respectively. The geographical coverage for Germany is the former Federal Republic of Germany.

Source: Henrekson and Johansson (1999).

Finally, while available data are fragmentary, there is some evidence to suggest that Sweden experienced low rates of new firm formation until the mid to late 1980s. Braunerhjelm and Carlsson (1993) calculate annual entry rates from 1920 to 1991 of new manufacturing firms with more than one employee. Their series show that rates of new firm formation in the Swedish manufacturing sector had became extremely low by the 1950s; it fell from approximately 4 to 2 percent from the 1920 s to the 1950s. The annual entry rate fell further to 1.5 percent in the $1970 \mathrm{~s}$, and the average entry rate was even lower in the 1980s.

To summarize, in comparisons among OECD countries, Sweden stands out as having a low rate of self-employment, a dominant role for larger firms, and highly concentrated ownership

\footnotetext{
13 A final owner is an owner which is not in turn owned by another firm such as a subsidiary within a corporate group. Typical final owners are pension funds, individuals and family foundations. Investment companies, on the other hand, are not final owners, since they are controlled by their own shareholders.
} 
and control of private-sector enterprises. The available evidence also points to low entry rates of new Swedish firms during a large part of the postwar period. This characterization of the employment structure of the Swedish economy was most extreme in the mid 1980s.

As a background to proposition 4 we will give a brief account of the development of savings and private wealth formation in Sweden after WW II. The development of Swedish net saving is indicated in Table 5. Net national saving rose between the 1950s and the 1960s, and thereafter declined sharply. For our purposes, the most noteworthy feature is the extremely important role of the government sector for net saving in the 1960s and 70s. Close to two thirds of net saving took place there, and a large part of these funds had to be channelled to the private sector. But, as long as the government shunned ownership of industry this pattern of national saving presupposed lending on a massive scale to the private sector. In particular, saving in the social insurance system increased from zero in 1959 to 4.7 percent of GDP in 1972. This saving took place within the mandatory national pension scheme, the ATPsystem, which was introduced in 1960. It accumulated large surpluses for a long time in a buffer fund, although the system was in effect a pay-as-you-go system, where entitlements had no relation to the rate of return on the assets in the fund. In the early 1970s the AP fund system accounted for more than 35 percent of the total stock of credit outstanding (Pontusson, 1992; Wickman, 1985).

Table 5 Net Saving as a Percentage of GDP, Annual Averages, 1950-96.

\begin{tabular}{lrrrrr}
\hline & $1950-59$ & $1960-69$ & $1970-79$ & $1980-89$ & $1990-96$ \\
\hline Total & 11.9 & 14.7 & 11.5 & 4.7 & 1.9 \\
Household & 4.5 & 3.6 & 1.8 & 0.5 & 3.1 \\
Corporate & 4.0 & 2.6 & 3.0 & 4.6 & 2.7 \\
Consolidated & 3.4 & 8.4 & 6.7 & -0.4 & -4.0 \\
government & & & & & \\
\hline
\end{tabular}

Source: Statistics Sweden, National Accounts.

When the AP fund was instituted it was decided that the fund should primarily invest in bonds. Since most borrowers are too small to issue bonds, a number of so-called intermediary credit institutions were formed. These institutions financed their lending through bond issues and granted credits to housing, production firms and municipalities. As a consequence, a very small fraction of AP fund lending has been directly to firms. For instance, in 19807 percent of total assets constituted direct lending to firms. This lending was mainly so-called "lending back" (återlån) based on the rule that employers were allowed to borrow up to half the amount they had paid in to the fund during the previous year. The potential for using this 
credit channel was therefore proportional to the wage bill of the firm. This type of lending was abolished in 1987.

The weak incentives for private individual savings also resulted in low levels of saving for households compared to other industrialized countries - see Table 6.

Table 6 Household Net Savings as a Share of Disposable Income in Sweden, OECD and OECD Europe, 1960-95 (\%).

\begin{tabular}{lrrrr}
\hline & $1960-69$ & $1970-79$ & $1980-89$ & $1990-95$ \\
\hline Sweden & 6.1 & 4.0 & 1.1 & 5.6 \\
OECD & 9.7 & 12.1 & 11.2 & 9.8 \\
OECD Europe & 12.0 & 13.6 & 11.6 & 10.9 \\
\hline
\end{tabular}

Source: OECD, Historical Statistics 1960-1980 and 1960-1995; OECD, Economic Outlook, Vol. 64, 1998.

As a result of the consistently low household savings rates in Sweden for several decades, individual financial wealth became very low by international comparisons. Such comparisons can only be made for a limited number of countries. In Table 7 we report data presented by Pålsson (1998) regarding financial wealth per capita in nine OECD countries in 1990 and 1995. Financial wealth per capita in Germany, Canada, France and Italy is generally 3-4 times larger than in Sweden and Japan. In the U.S. it is approximately six times larger than in Sweden. ${ }^{14}$

Table 7 Financial Wealth per Capita in Nine OECD Countries, 1990 and 1995 (Current US dollars).

\begin{tabular}{lrr}
\hline Country & 1990 & 1995 \\
\hline Canada & 28,233 & 33,359 \\
France & 23,580 & 41,347 \\
Germany & 28,463 & 45,328 \\
Italy & 32,374 & 35,790 \\
Japan & 39,707 & 94,038 \\
Norway & 2,857 & 5,179 \\
Spain & 9,345 & 12,084 \\
Sweden & 7,152 & 13,516 \\
U.S. & 51,827 & 76,760 \\
\hline
\end{tabular}

Source: Pålsson (1998), based on OECD, Financial Statistics (various years).

\footnotetext{
14 Lindh and Ohlsson (1998) find that a more unequal wealth distribution covaries positively with the share of self-employed. The combination of low private savings and an extremely even distribution of these low savings implies that fewer people either from themselves or from their associates, friends or relatives are able to raise the requisite equity to realize their business projects.
} 
The low level of private wealth formation obviously tended to diminish the role of households as owners in the corporate sector. We also saw in the previous section that the tax system favored financing by debt and by retained earings relative to equity financing. The system was thus favoring investments and accumulation of capital in the corporate sector at the same time as it was unfavorable towards private wealth creation. The system also created an environment where the stock market, because of extremely low valuations did not translate the capital accumulation in the corporate sector into household wealth.

The replacement value of the capital stock in the corporate sector was generally much higher than the stock market values of the firms. This is illustrated by Figure 1. It shows that Tobin's $q$ fell from 60 percent to 30 percent between 1970 and 1980. According to calculations in Södersten (1984) Tobin's $q$ was approximatively unity in 1960. Another indication of the low market values are given by the price earnings ratios for the large Swedish companies. The figure reports the P/E-ratios for Ericsson, Electrolux and Atlas Copco, respectively. In the early 1970s, companies like these were typically valued at P/Eratios around 2-3.

As a result of the low level of private wealth creation and the strong disincentives towards private ownership in the corporate sector, the share of private ownership in the corporate sector diminished dramatically. This is illustrated in Figure 2.

Figure 1 Tobin's $q$ in 1970-80 in the Swedish Engineering Industry and the Evolution of the P/E-Ratio in Three Swedish Engineering Firms in 1970-98.

Enclosed

Note: Tobin's $q$ is defined as the stock market value/calculated replacement cost for the 13 leading engineering corporations in Sweden; the P/E-ratio is defined as the stock market value/profits before tax and extraordinary items. The evolution of the the P/E-ratios have been fitted to a linear trend.

Source: Tobin's q: Södersten (1984); P/E-ratio: Findata.

Let us now move to the concentration of private ownership and Schumpeter's proposition 4. We will start by examining the distribution of ownership in 1950. According to Spånt's calculations the households then held 75 percent of all Swedish listed stock. The calculations apply to final owners, which implies that ownership by investment companies and other intermediate owners has been netted out. The final owner categories are households, institutions and foreign owners. Private ownership was highly concentrated at this point. This is clearly documented by Lindgren (1953) in a study based on the 1945 Census. He shows that 6-7 percent of the stock owners controlled 65-70 percent of the stock market value. His 
findings regarding the ownership control in the large companies (more than 500 employees) are of even greater interest in our context. In no less than 60 percent of the large firms one single individual represented the majority of the votes at the shareholders' general meeting. In more than 90 percent of the firms three owners or less constituted the majority at the shareholders' meeting.

Figure 2 The Distribution of Ownership of Swedish Quoted Stocks across Ownership Categories, 1950-97.

\section{Enclosed}

Source: Spånt (1975), Norrman and McLure (1997) and Statistics Sweden.

The increasing share of ownership of institutions was paralleled by an increased concentration of private ownership. Or to be more specific: The Wallenberg family gradually acquired an increasing dominance on the boards of the largest Swedish firms during the postwar period. Glete (1994) studies the power structure of the largest firms in 1925, 1945, 1967 and 1990. In 1925 the Wallenberg family controlled two of the 25 largest firms. By 1945 this had increased to five and by 1967 they controlled ten of the largest 25 firms. In 1990 the Wallenberg family controlled the board of nine of the 25 largest firms.

In addition, frequently the same individuals or families held a majority position in a number of firms. Against this background the then leader of the Communist party C. H. Hermansson coined the expression "the fifteen families" in his 1962 book Monopol och storfinans (Monopoly and Big Business). According to him these fifteen families controlled Swedish industry. This view of the world was later confirmed by the government commission on ownership concentration (Koncentrationsutredningen, SOU 1967:7) and by Glete (1987, 1994). According to Shumpeter's analysis in CSD Swedish industry had already at this stage come pretty close to the point where the socialization of the industrial sector would become politically inevitable. As we have discussed at some length, economic policies encouraged an increasing institutionalization of corporate ownership, but it also spurred the development towards increased concentration of ownership and firms.

At first sight it may appear paradoxical that a single family has been able to expand its power so tangibly, while economic policies have been aimed at curtailing private ownership. In practice however, the control of the firms has been based on a progressively smaller share of the equity base of the firms. It appears that the Wallenberg family was far more capable of exploiting the ownership void that opened as a result of the far-reaching institutionalization of corporate ownership during the postwar period. Anyway, the upshot was an extreme 
concentration of private ownership in Swedish industry, which is in accordance with proposition 4.

According to Schumpeter concentrated ownership breeds a hostility towards capitalism, while a large number of entrepeneurs and a widespread ownership creates a political climate that is favorable towards the capitalist system. We may now move on to the question whether the general public in Sweden, as predicted by proposition 5, grew increasingly hostile towards capitalism.

In Table 8 we report the results from two questionnaires where a representative sample of individuals have been asked about their attitudes towards entrepreneurship and business conditions. In 1978 only 30 percent of the respondents believed that it was important to encourage entrepreneurship and firm formation. In the 1980s people's attitudes on this issue changed dramatically and by the mid 1980s approximately four quarters thought this was important. Perhaps even more striking is the fact that in 1978 only 37 percent of the respondents believed that business leaders/entrepreneurs were most efficient in running a firm. In the 1990s this had also changed and by 1997 the percentage who thought that business leaders/entrepreneurs were the most efficient was so high that the question had virtually lost its relevance.

Table 8 Results from Two Repeated Cross-Section Studies of Attitudes towards Entrepreneurship.

I. Question: Is it important to encourage entrepreneurship and firm formation? Share of respondents believing that it is important:

\begin{tabular}{lrrrrrr}
\hline Year & 1963 & 1967 & 1978 & 1981 & 1985 & 1997 \\
Share (\%) & 50 & 41 & 30 & 72 & 74 & 88 \\
\hline
\end{tabular}

II. Question: Who do you think is capable of running a firm most efficiently? Choose between (1) business leaders/entrepreneurs, (2) trade union representatives, and (3) do not know/equally good. Share of respondents believing that business leaders/entrepreneurs were most efficient:

\begin{tabular}{lrrrr}
\hline Year & 1978 & 1982 & 1995 & 1997 \\
Share (\%) & 37 & 55 & 80 & 90 \\
\hline
\end{tabular}

Source: SIFO, Demoskop and The Federation of Swedish Employers, SAF.

Overall the Swedish corporate sector was at the end of the 1970s in a state quite close to the visions formulated by the blue-collar trade union (LO) and Wigforss just after WW II. The 
corporate sector was dominated by a small number of very large firms that were controlled by an extremely small number of people and a very concentrated stock of wealth. According to Schumpeter's (1942) analysis the time should be ripe for a transition to socialism.

\section{Towards Socialism}

In section 5 we have shown that the Swedish economy during the period 1945 to 1980 complied rather closely with the first five Schumpeterian propositions presented in section 2. In this section we will analyze to what extent the sixth and the most important proposition in $C S D$ was fullfilled.

During the 1970s, the blue-collar workers' trade union, LO, was very successful in inducing the government to take a number of legislative measures aiming at giving labor direct influence on corporate decision making. Prime examples are union representation on corporate boards of directors, and the extension of collective bargaining through the Codetermination Act of 1976 (see Pontusson, 1992).

The underlying ideology was at least to some extent inspired by the Marxian theory of value, where all surplus value is said to emanate from labor. Hence, labor is the factor of production that should have the most saying in management decisions. Of course, these ideas are greatly removed from the idea that the entrepreneur is of key importance in the economy since he or she "specializes in taking responsibility for and making judgmental decisions that affect the location, form and the use of goods, resources, or institutions" (Hébert and Link, 1989, p. 47).

The radicalization of the labor movement during the 1970s also entailed explicit demands for increased collective ownership. (In this process the intellectuals, in line with Schumpeter's proposition 5, played an important role.) Such demands had from time to time surfaced within the labor movement even earlier on. Already in 1961 the LO Congress had before it a suggestion to introduce so-called branch equalization funds, where high-profit firms should be forced to set aside part of the pay increase from which they abstained as a result of solidarity bargaining. ${ }^{15}$ Such funds were seen as a means of avoiding the consequences for the wealth distribution following from a solidaristic wage policy (LO, 1961). A first important step towards increased collective ownership was taken in 1974 when a fourth National Pension Fund (AP Fund) was introduced with the aim of investing in the stock

\footnotetext{
15 According to Johansson and Magnusson (1998, pp. 115-116) the ultimate vision of the team writing this report was "capitalism without capitalists".
} 
market. Until then the National Pension Funds had been totally banned from equity investments.

Explicit demands for increased collective ownership on a much grander scale were voiced at the 1976 LO Congress where Rudolf Meidner and his collaborators presented a plan for an inexorable transfer of ownership from private hands to collective "wage-earner funds" (löntagarfonder) - see LO (1976) and Meidner (1978). This can be interpreted as a concrete plan for materializing Wigforss original vision to convert the large corporations to "social enterprises without owners".

The wage-earner fund scheme entailed a gradual transfer of ownership of all firms with more than 50 (or possibly 100) employees to wage-earners as a collective group. The firms should be obligated to issue new shares to the wage-earner funds corresponding to a value of 20 percent of the profits. Thus, the transfer of ownership would be more rapid, the more profitable the firm. Incidentally, assuming a rate of profit of 10 percent, it would take 35 years for the wage-earner funds to obtain a majority equity share in the individual company. The wage-earner equity thus acquired was intended to remain within the firm as working capital. The voting rights and other ownership prerogatives were to be exercized by the local unions until the wage-earner shares represented 20 percent of the total equity. At the point where the ownership share exceeded 20 percent the funds ownership rights would be transferred to more centralized bodies controlled by the national unions but including representatives of other interests in society. It is interesting to note that this form of socialization was exactly in line with Schumpeter's prediction of "laborism" as the last stage of capitalism.

Since the shares were not supposed to be traded, labor's influence over the allocation of investments across firms was not intended to increase, at least not in theory. But it was quite clear that the authors of the report saw the wage-earner funds as a means to give the labor unions the power to make corporate investment decisions of strategic significance for the whole society. One claim from LO was that wage-earner funds might prevent Swedish multinational firms from moving employment and R\&D abroad (LO, 1976, pp. 68-76, 87$88)$.

These explicit proposals to infringe on private ownership implied that the labor movement broke away from the old historical compromise struck in the late 1930s. In due course therefore, the wage-earner fund proposals met unprecedented opposition from capital owners. Leading Swedish capital owners literally took to the streets. On October 4, 1983 capital owners rallied across the country in defense of the right to retain ownership and control of 
their firms. Moreover, the original Meidner proposal never gained full acceptance within the Social Democratic Party and subsequent joint proposals from LO and the Social Democratic Party were less radical than the original Meidner plan. Politically, any proposals were blocked from being carried out until the Social Democrats returned to power in 1982. At this stage the public opinion had shifted against wage-earner funds, but under pressure from LO the government introduced a considerably watered-down version of wage-earner funds in 1984. The five wage-earner funds thus introduced were financed by a 0.2 percent pay-roll tax and a 20 percent tax on real profits above SEK 1 million, which in practice added approximately five percentage points to the formal tax rate (Agell, Englund and Södersten, 1995). Most importantly, the build-up of the wage-earner funds was restricted to seven years. The funds were abolished in 1992 by the then non-socialist government.

\section{The Turning-Point}

We have in a somewhat stylized way described the development in and the policy towards the corporate sector as a linear process where in the end socialism in one form or another would replace capitalism. The wage-earners funds seem to fit perfectly into that model. However, the introduction of the funds and their subsequent abolishment in fact became a turning-point for the road towards socialism as we have described it.

In the 1980s Sweden followed the general trend of deregulation prevailing in the OECD economies during this time. There were also a couple of large tax reforms that worked towards a more neutral treatment than before of different owners and different sources of finance. Tax progression was also substantially lowered. A more detailed picture of these changes was given in section 4. A general result of these changes was that the Swedish economy to a much larger extent than before became integrated with the other capitalist OECD economies.

An important legacy of the old policies is that the abolitionof investment controls has led to a dramatic increase in foreign ownership of the Swedish corporate sector during the last few years (see Figure 2). To a certain extent this is a development experienced by all industrialized countries. However, Sweden is involved in this process to a larger extent than most other countries. ${ }^{16}$ This could to a large extent be explained by the structural features of

\footnotetext{
16 Foreign direct investment, inward as well as outward, plays a relatively larger role in the Swedish economy than in the economies of most other industrialized countries. See Jakobsson (1999, Table 4, p. 347).
} 
the Swedish economy that we have discussed in this article. Of special importance is the crucial role of the large corporations in combination with the low level of private wealth in Sweden.

A very interesting question is what the forces were that broke the trend. The answer must necessarily be speculative. During the seventies there were two important, but not necessarily independent, changes in the environment that altered the prospects for a socialist policy. First, during the 1970s there was a marked change in the international view of the market versus the planned economy. During the first two decades of the postwar period both politicians and economists harbored a strong belief in the possibility of planning the national economy. In this period a growing role for the public sector in the economy was with few exceptions seen as an inexorable trend. Many scholars such as the Nobel Laureate Jan Tinbergen (1968) predicted that there would be a convergence between the economies in the West and the planned economies in Eastern Europe. This would result from the combined effect of increased state planning in the West and more flexible bureaucracies and a gradual easing of the political repression in the East. In this process Sweden was often heralded as a role model among the Western countries. However, during the latter half of the 1970s there was a renaissance for the free market economy in the leading industrialized countries. Among other things, this was a result of the disappointing effects of public interventions and planning in the West and the increasingly obvious failure of the planned economies of Eastern Europe. ${ }^{17}$ In addition, the Swedish growth performance was distinctly worse than that in most other industrialized countries (Lindbeck, 1997; Henrekson, 1996). This reduced the confidence in the kind of interventionst policies that Sweden had pursued during the last couple of decades.

Relating these developments to Schumpeter one must conclude that he did underestimate the efficiency problems in socialist systems. The experiences in Eastern Europe also underlined the impossibility of combining full-fledged socialism with democracy. To summarize: Schumpeter's assertion that socialism of course can work, had been refuted by real world developments, and this assertion was one of the building blocs in his scenario.

${ }^{17}$ See Yergin and Stanislaw (1998) for a comprehensive but easily accessible presentation of this development. 
Second, towards the end of the 1970s the previous trend of a growing predominance of giant corporations and the waning importance of small (entrepreneurial) firms was broken (Loveman and Sengenberger, 1991). The average firm and establishment size began to decrease and the individual entrepreneur once again came to play an important role in economic development. ${ }^{18}$

There are several explanations to this development. To begin with, technical change no longer seems to give rise to economies of scale in production the way it used to. On numerous occasions, small scale, flexibility and customer proximity may lead to superior performance in smaller production units (Audretsch and Thurik, 2000). Moreover, the comprehensive changes in technologies and market conditions give rise to new business opportunities that can often be most suitably exploited within newly formed business organizations (Baldwin and Johnson, 1999; Acs and Audretsch, 1990). Finally, it is likely that the deregulatory process that was initiated at the end of the 1970s in the leading countries undermined the monopoly position of many of the large corporations at the time, which created new business opportunities for small firms and new entrants. ${ }^{19}$ Ronald Reagan epitomized the situation in the early 1980s as follows: "We have lived through the age of Big Industry and the age of the giant corporation. But I believe that this is the age of the entrepreneur". ${ }^{20}$ To the extent that this presumption was true, the structural basis of Schumpeter's theory and Wigforss' vision was gone.

\section{Concluding Remarks}

In this paper we have shown that key economic policies in Sweden precipitated the gradual fulfillment of Schumpeter's visions in CSD. In particular, it is worth emphasizing that the increasing hostility towards capitalism foreseen by Schumpeter also materialized. As a result, the way was paved for proposals entailing a democratic and peaceful transition to socialism. However, these proposals were eventually abolished and Sweden turned away from socialism. This turning point highlights a couple of flaws in Schumpeter's scenario. First, real world developments refuted his assertion that socialism could work as efficiently as capitalism and that it could readily be combined with democracy. Second, he did not foresee

\footnotetext{
18 Blau (1987) documents that in the early 1970s the secular downward trend in the self-employment rate was reversed and it has been rising ever since. The strongest factor behind this development is that total factor productivity began to grow faster in industries amenable to self-employment relative to other industries.

${ }^{19}$ For an overview of studies providing corroborating evidence on these points, see the recent surveys in Wennekers and Thurik (1999) and Carlsson (1999).

20 Quoted from Brown, Hamilton and Medoff (1990, p. 1).
} 
that technological change once again would pave the way for the individual entrepreneur in the capitalist economies.

The global renaissance for small business and independent entrepreneurship has probably contributed to the increased popularity of capitalism. Therefore it seems as though Schumpeter was right in his key assumption that the entrepreneur is the political backbone of capitalism.

Finally, structural and technological conditions may once more change in such a way that small businesses and individual entrepreneurs wane in importance. Such a scenario cannot be ruled out. There are at least some indications that large scale is gaining in importance: the current wave of mergers and acquisitions among large multinationals, economic globalization resulting in strong scale economies in distribution and marketing, at least in the pharmaceutical industry we see important scale economies in product development, and empirical evidence showing that optimal firm size is growing in the service sector is rapidly accumulating (Davis, Haltiwanger and Schuh, 1996). Should these tendencies prove to be a new trend, we could again experience the growing hostility towards capitalism that Schumpeter foresaw in Capitalism, Socialism and Democracy. It is however difficult to believe that socialism would come back as a credible alternative.

References

Acs, Zoltan J. and Audretsch, David B. (1990), Innovation and Small Firms. Cambridge, MA: MIT Press.

Agell, Jonas, Englund, Peter and Södersten, Jan (1995), Svensk skattepolitik i teori och praktik. Expert report No.1 to SOU 1995:104. Stockholm: Fritzes.

Audretsch, David B. and Thurik, A. Roy (2000), Journal of Evolutionary Economics 10(1-2), 17-34.

Baldwin, John R. och Johnson, Joanne (1999), "Entry, Innovation and Firm Growth". In Acs, Zoltan J. (ed.), Are Small Firms Important? Their Role and Impact. Dordrecht: Kluwer.

Bergström, Villy (1973), Kapitalbildning och industriell demokrati. Stockholm: Tidens förlag.

Bergström, Villy (1982), Studies in Swedish Post-War Industrial Investments. Dissertation. Department of Economics, Uppsala University.

Blanchflower, David G. and Oswald, Andrew J. (1998), “What Makes an Entrepreneur?“ Journal of Labor Economics 16(1), 26-60.

Blau, David M. (1987), “A Time-Series Analysis of Self-Employment in the United States.” Journal of Political Economy 95(3), 445-467.

Braunerhjelm, Pontus and Carlsson, Bo (1993), ’Entreprenörskap, småföretag och industriell förnyelse 196891.” Ekonomisk Debatt 21(4), 317-328.

Brown, Charles, Hamilton, James and Medoff, James (1990), Employers Large and Small. Cambridge, MA: Harvard University Press.

Carlsson, Bo (1999), "Small Business, Entrepreneurship, and Industrial Dynamics.” In Acs, Zoltan (ed.), Are Small Firms Important? Dordrecht: Kluwer.

Davis, Steven J., Haltiwanger, John and Schuh, Scott (1996), Job Creation and Destruction. Cambridge, MA: MIT Press.

Davis, Steven J. and Henrekson, Magnus (1997), ’Industrial Policy, Employer Size and Economic Performance in Sweden.” In Freeman, Richard B., Topel, Robert and Swedenborg, Birgitta (eds.), The Welfare State in Transition. Chicago: University of Chicago Press.

European Observatory for SMEs (1995), Third Annual Report 1995. Zoetermeer, the Netherlands: EIM Small Business Research and Consultancy. 
Evans, David S. and Jovanovic, Boyan (1989), ”An Estimated Model of Entrepreneurial Choice under Liquidity Constraints." Journal of Political Economy 97(4), 808-827.

Evans, David S. and Leighton, Linda S. (1989), "Some Empirical aspects of Entrepreneurship." American Economic Review 79(3), 519-535.

Fukao, Mitsuhiro and Hanazaki, Masaharu (1987), 'Internationalization of Financial Markets and the Allocation of Capital.” OECD Economic Studies, No. 8, 35-92.

Fölster, Stefan and Peltzman, Sam (1997), "The Social Cost of Regulation and Lack of Competition in Sweden.“ In Freeman, Richard B., Topel, Robert and Swedenborg, Birgitta, (eds.), The Welfare State in Transition. Chicago: University of Chicago Press.

Galbraith, John K. (1958), The Affluent Society. Boston: Houghton Mifflin.

Galbraith, John K. (1967), The New Industrial State. London: Hamish Hamilton.

Glete, Jan (1987), Ägande och industriell omvandling. Ägargrupper, skogsindustri, verkstadsindustri 18501950. Stockholm: SNS Förlag.

Glete, Jan (1994), Nätverk i näringslivet. Stockholm: SNS Förlag.

Granstrand, Ove and Alänge, Sverker (1995), ’The Evolution of Corporate Entrepreneurship in Swedish Industry - Was Schumpeter Wrong?" Journal of Evolutionary Economics 5(2), 133-156.

Hébert, R.F. and Link, A.N. (1989), "In Search of the Meaning of Entrepreneurship." Small Business Economics 1(1), 39-49.

Henrekson, Magnus (1992), "Sweden: Monetary and Financial System." In Newman, Peter, Milgate, Murry and Eatwell, John (eds.), The New Palgrave Dictionary of Money \& Finance. London and New York: MacMillan.

Henrekson, Magnus (1996), "Sweden's Relative Economic Performance: Lagging Behind or Staying on Top?." Economic Journal 106(439), 1747-1759.

Henrekson, Magnus and Johansson, Dan (1999), 'Institutional Effects on the Evolution of the Size Distribution of Firms." Small Business Economics 12(1), 11-23.

Hermansson, Carl-Henrik (1962), Monopol och storfinans. Stockholm: Arbetarkulturs förlag.

Hernes, Gudmund (1991), "The Dilemmas of Social Democracies: The Case of Norway and Sweden." Acta Sociologica 34(2), 239-260.

Holtz-Eakin, D., Joulfaian, D. and Rosen, H.S. (1994), "Sticking It out: Entrepreneurial Survival and Liquidity Constraints." Journal of Political Economy 102(1), 53-75.

Jagrén, Lars (1993), ”De dominerande storföretagen." In Den långa vägen. Stockholm: The Research Institute of Industrial Economics, IUI.

Jakobsson, Ulf (1999), "Storföretagen och tillväxten”. In Calmfors, L. and Persson, M. (eds.), Tillväxt och ekonomisk politik. Lund: Studentlitteratur.

Johansson, Anders L. and Magnusson, Lars (1998), LO andra halvseklet. Fackföreningsrörelsen och samhället. Stockholm: Atlas.

Jonung, Lars (1994), "The Rise and Fall of Credit Controls: The Case of Sweden, 1939-89.” In Bordo, Michael D. and Capie, Forrest (eds.), Monetary Regimes in Transition. Cambridge: Cambridge University Press.

King, Mervyn A. and Fullerton, Don, (eds.), (1984), The Taxation of Income from Capital. A Comparative Study of the United States, the United Kingdom, Sweden and West Germany. Chicago: Chicago University Press.

Kirzner, Israel M. (1973), Competition and Entreprenurship. Chicago: University of Chicago Press.

Knight, Frank H. (1921), Risk, Uncertainty and Profit. New York: Houghton Mifflin.

Korpi, Walter (1982), "The Historical Compromise and Its Dissolution.” In Rydén, B. and Bergström, V. (eds.), Sweden: Choices for Economic and Social Policy in the 1980s. London: George Allen \& Unwin.

Lindbeck, Assar (1997), "The Swedish Experiment.” Journal of Economic Literature 35(3), 1273-1319.

Lindgren, Gunnar (1953), "Shareholders and Shareholder Participation in the Larger Companies' Meetings in Sweden." Weltwirtschaftliches Archiv, 71(2), 281-298.

Lindh, Thomas and Ohlsson, Henry (1996), "Self-Employment and Windfall Gains: Evidence from the Swedish Lottery.” Economic Journal 106(439), 1515-1526.

Lindh, Thomas and Ohlsson, Henry (1998), "Self-Employment and Wealth Inequality“. Review of Income and Wealth 44(1), 25-42. 
Lindholm Dahlstrand, Åsa (1997), "Growth and Inventiveness in Technology-Based Spin-off Firms." Research Policy 26(3), 331-344.

LO (1953), Trade Unions and Full Employment. London: George Allen \& Unwin.

LO (1961), Fackföreningsrörelsen och företagsdemokratin. Stockholm. (Published in English in 1963 as Economic Expansion and Structural Change. London: George Allen \& Unwin.)

LO (1976), Kollektiv kapitalbildning genom löntagarfonder. Stockholm.

Loveman, Gary and Sengenberger, Werner (1991), "The Reemergence of Small-Scale Production: An International Comparison.” Small Business Economics 31(1), 1-37.

Lybeck, Johan A. (1984), Hur stor är den offentliga sektorn? Lund: Liber Förlag.

Meidner, Rudolf (1978), Employee Investment Funds. An Approach to Collective Capital Formation. London: George Allen \& Unwin.

Myrdal, Gunnar (1944), "Höga skatter och låga räntor.” In Studier i ekonomi och historia tillägnade Eli F. Heckscher. Uppsala: Almqvist \& Wicksell.

Norrman, Erik and McLure, Charles E. (1997), "Tax Policy in Sweden.” In Freeman, Richard B., Topel, Robert and Swedenborg, Birgitta (eds.), The Welfare State in Transition. Chicago: University of Chicago Press.

Pontusson, Jonas (1992), The Limits of Social Democracy. Investment Politics in Sweden. Ithaca: Cornell University Press.

Pålsson, Ann-Marie (1998), “De svenska hushållens sparande och förmögenheter 1986-1996.” Mimeo. Department of Economics, Lund University.

Rosenberg, Nathan (2000), Schumpeter and the Endogeneity of Technology: Some American Perspectives. London: Routledge.

Schumpeter, Joseph A. (1911, 1934), The Theory of Economic Development. Cambridge, MA: Harvard University Press. First published in German in 1911.

Schumpeter, Joseph A. (1942), Capitalism, Socialism and Democracy. New York: George Allen \& Unwin.

SOU 1967:7, Ägande och inflytande inom det privata näringslivet. Koncentrationsutredningen. Stockholm: Allmänna Förlaget.

Spånt, Roland (1975), Förmögenhetsfördelningen i Sverige. Stockholm: Prisma.

Swedberg, Richard (1997), "Schumpeter in Sweden.” Scandinavian Economic History Review 45(2), 113-130.

Södersten, Jan (1984), "Sweden.” In King, Mervyn A. and Fullerton, Don (eds.), The Taxation of Income from Capital. A Comparative Study of the United States, the United Kingdom, Sweden and West Germany. Chicago: University of Chicago Press.

Södersten, Jan (1993), "Sweden." In Jorgenson, Dale W. and Landau, R. (eds.), Tax Reform and the Cost of Capital. An International Comparison. Washington D.C: Brookings.

Tinbergen, Jan (1968), Development Planning. London: Weidenfeld \& Nicholson.

Yergin, Daniel and Stanislaw, Joseph (1998), The Commanding Heights. New York: Simon \& Schuster.

Van Praag, C. Mirjam and Van Ophem, Hans (1995), ”Determinants of Willingness and Opportunity to Start as an Entrepreneur." Kyklos 48(4), 513-540.

Veblen, Thorstein (1923), Absentee Ownership and Business Enterprise in Recent Times: The Case of America. New York: Scribner's.

Wennekers, Sander and Thurik, Roy (1999), "Linking Entrepreneurship and Economic Growth." Small Business Economics 13(1), 27-55.

Wickman, Krister (1985), ”Allmänna Pensionsfonden - dess roll i pensionssystemet och på den svenska kapitalmarknaden.” In Myhrman, Johan (ed.), Svensk kapitalmarknad inför morgondagen. Stockholm: EFI.

Wigforss, Ernst (1952), Socialism i vår tid. Stockholm: Tidens förlag.

Wigforss, Ernst (1956), Efter välfärdsstaten. Malmö: Framtiden. 